$\frac{\text { DE }}{\text { DE GRUYTER }}$ OPEN

\title{
CHANGES OF NITROGEN COMPOUNDS DURING ENSILING OF HIGH PROTEIN HERBAGES - A REVIEW*
}

\author{
Maja Fijałkowska*, Barbara Pysera, Krzysztof Lipiński, Danuta Strusińska \\ Department of Animal Nutrition and Feed Management, University of Warmia and Mazury in Olsztyn, \\ Oczapowskiego 5, 10-718 Olsztyn, Poland \\ •Corresponding author: maja.fijalkowska@uwm.edu.pl
}

\begin{abstract}
Losses of crude protein during ensiling of herbages, in contrast to carbohydrates, do not affect the reduction of its content; their form is changed into greater solubility non-protein compounds and also highly degraded forms, which lower the efficiency of the microbial protein synthesis in the rumen. These processes are accompanied by a change of amino acid composition of herbage protein and decrease in intestinal digestibility of protein from feeds as a result of the formation of indigestible complexes with carbohydrates (ADIN). Reduction of protein degradation in silages is achieved by accelerated acidity through addition of acids or dominance of homofermentative bacteria. The positive effects of fermentation inhibitors or sorbents use, as well as the wilting of raw material on the level and rate of protein degradation were demonstrated by many researchers. A greater contribution of protein nitrogen and reduction of deamination in silages can also be obtained by using bacteria inoculants. Increasing the proportion of protein nitrogen is accompanied by the improved efficiency of microbial protein synthesis.
\end{abstract}

Key words: silage, legumes, proteolysis, crude protein, nitrogen fractions

Current interest in the excessive nitrogen emission to the environment, in the form of ammonia to the atmosphere and nitrates into groundwater, in animal production primarily concerns ruminants, and results from low utilization of nitrogen (Huhtanen, 2010). The quantity of the nitrogen pool leaving the animal body depends on the efficiency of nitrogen conversion which in milk production is $18-30 \%$, and in meat production 10-20\%, which is far below the potential of cattle, which exceeds 40\% (Dewhurst et al., 1996; Frank et al., 2002). These losses result from the low efficiency of microbial protein synthesis in the rumen, caused on the one hand by rapid and excessive degradation of plant protein, and on the other hand by slow release

\footnotetext{
*This work was supported by the State Committee for Scientific Research, Grant No. N N311 234238 .
} 
of energy from cell wall components in the rumen (Davies et al., 2005). For these reasons, many studies have focused on strategies to improve nitrogen balance in milk and meat production based on the grass and legume silages (Moorby et al., 2002; Nadeau et al., 2007). Improving the efficiency of nitrogen utilization can be achieved by improving the energy supply of rumen microorganisms and reducing the degree of protein degradation in the rumen. A common strategy aimed at improving nitrogen energy balance is the use of maize silage and high-starch feeds. However, the proportion of the latter is limited due to the risk of subclinical rumen acidosis (Moorby et al., 2002; Nadeau et al., 2007). Increasing the proportion of low degradability protein in the rumen is applied in practice through, for instance, supplementation with extracted meals, which increases protein synthesis, but impairs the utilization of total nitrogen (Huhtanen and Shingfield, 2005). In practice, little attention is paid to the improvement of the protein composition of roughage that can be achieved by restrictive fertilization of fodder, and above all, by reducing the processes of proteolysis during ensiling of high-protein herbages (Davies et al., 2005; Purwin et al., 2010).

One of the main causes of lower degree of nitrogen utilization in the rumen is extensive hydrolysis of protein during ensiling (Jones, 2000). This process proceeds through two pathways.

In the first phase of ensiling, protein degradation to non-protein nitrogen compounds (NPN) takes place under aerobic conditions, mainly due to the action of proteolytic plant enzymes (Gąsior and Brzóska, 2002). Proteases in lucerne exhibit a special activity. Ohshima and McDonald (1978) showed that the plant enzymes are known to decarboxylate aspartic acid to alanine and glutamic acid to $\gamma$-aminobutyric acid (GABA).

The second pathway of proteolysis is carried out by lactic acid bacteria, acetic acid bacteria, or butyric acid bacteria. Amino acids are broken down by deamination to form ammonia and suitable organic acids, and by the decarboxylation to form $\mathrm{CO}_{2}$ and biogenic amines (Gąsior and Brzóska, 2002).

Another factor limiting the use of nitrogen in the rumen is the large decrease in the content of soluble carbohydrates in silages resulting in a deficiency of energy substrates for rumen microorganisms. These losses are visible in the low silage nitrogen utilization by ruminants and may range, by various authors, from 44 to $87 \%$ of crude protein (Papadopoulus and McKersie, 1983; Albrecht and Muck, 1991; Jones et al., 1995). Dewhurst et al. (2003) showed that the degradability of nitrogen compounds from red clover silage $(65 \%)$ in rumen was lower than that from white clover (67\%), grass (70\%) and lucerne silage (72\%). This may confirm an improved efficiency of microbial synthesis in dairy cows fed red clover silage compared with grass silage (Davies et al., 1999).

\section{Characteristics of nitrogen fractions in herbages and silages at different stages of silage production}

Changes in chemical composition and quality of herbages begins at the time of cutting plants and lasts until the intake of conserved forages by animals (Figure 1). Crude protein contained in the plant material is a heterogeneous mixture of several proteins and non-protein nitrogen compounds. In total nitrogen of herbage, true pro- 
tein constitutes 75 to 90\% (Jones, 2000; Givens and Rulquin, 2004; Slottner and Bertilsson, 2006; Martineau et al., 2007), and the rest are non-protein nitrogen compounds (NPN), among which one may find organic nitrogen as free amino acids, peptides of different chain length, amides, nucleotides, chlorophyll and mineral nitrogen as nitrates.

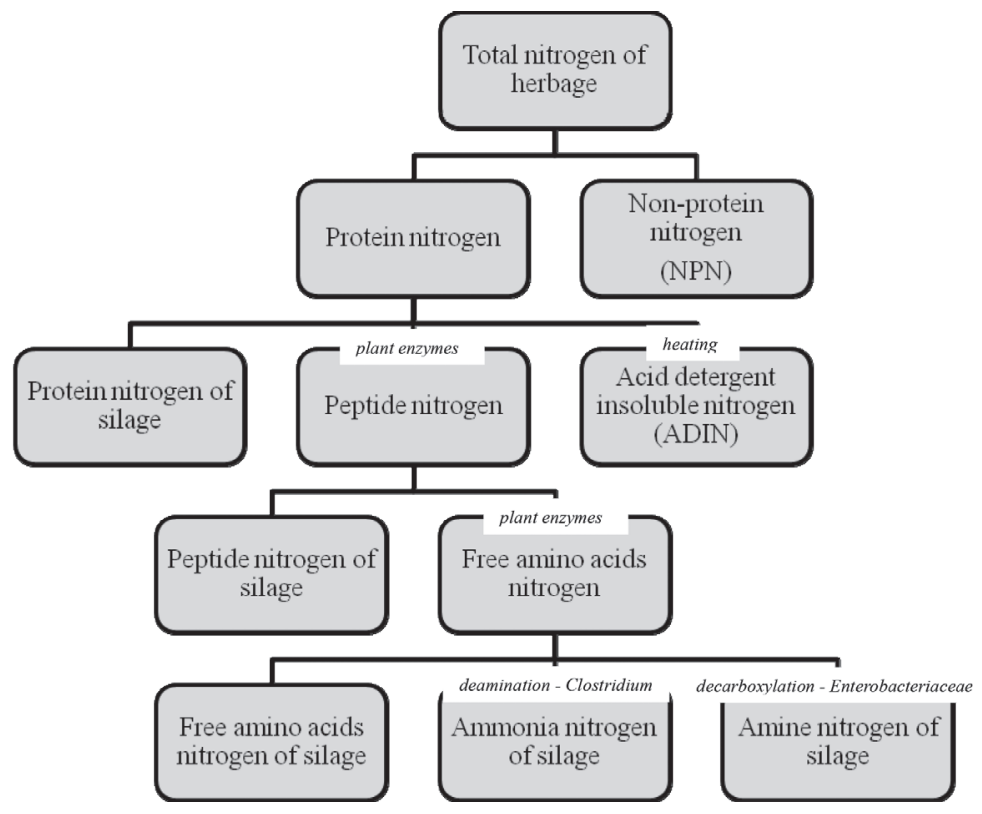

Figure 1. Composition of total nitrogen of silage

Non-protein nitrogen compounds of herbages contain a small amount of ammonia nitrogen, which is less than $1 \%$ of total nitrogen (Ohshima and McDonald, 1978; McDonald et al., 1991). Majority of the nitrogen absorbed by plants from the soil is reduced from $\mathrm{NO}_{3}$ to $\mathrm{NO}_{2}$ by nitrogen reductase and then to $\mathrm{NH}_{4}$. Ammonia is not accumulated in plants, even though it may be absorbed by roots (Buxton and O'Kiely, 2003). The only form of inorganic nitrogen which can accumulate in plants are nitrates. This happens when the nitrogen supply exceeds the plant demand for growth.

The rate at which nitrates are converted to organic nitrogen in plants depends on the intensity of photosynthesis. Environmental factors limiting photosynthesis in leaves, such as shading, drought, disease, pesticides and others often lead to an increased concentration of $\mathrm{NO}_{3}$. Grasses are more likely to accumulate $\mathrm{NO}_{3}$, particularly in lower stem internodes (Buxton and O'Kiely, 2003).

Legumes accumulate less nitrate due to low fertilization and symbiotic nitrogen fixation in the form of $\mathrm{NH}_{3}$. Nitrate toxicity in livestock production can occur at high $\mathrm{N}$-fertilization (Buxton and O'Kiely, 2003).

Almost all true protein of plants has enzymatic character and its existence is connected with growth and biochemical functions of cells (Table 1). Chloroplasts con- 
tain approx. $75 \%$ of the total amount of this component in leaves. The predominant enzyme (approx. 50\% of soluble protein) is a ribulose-1,5-bisphosphate carboxylase-oxygenase (RuBisCo).

Table 1. Characteristics of herbage protein (Van Vuuren, 1993)

\begin{tabular}{|c|c|c|c|}
\hline $\begin{array}{c}\text { Protein } \\
\text { solubility }\end{array}$ & Fractions & Location in cell & Amount \\
\hline \multirow[t]{3}{*}{ Soluble proteins } & Fraction $1-\mathrm{RuBisCo}$ & chloroplasts & $30-40 \%$ \\
\hline & $\begin{array}{l}\text { Fraction } 2 \text { - contains approx. } 25 \% \\
\text { of leaf protein }\end{array}$ & chloroplasts, cytoplasm & $15-20 \%$ \\
\hline & Free amino acids & & $5-10 \%$ \\
\hline \multirow[t]{2}{*}{ Insoluble proteins } & Chlorophyll-protein complexes & chloroplast membranes & $\approx 30 \%$ \\
\hline & Cell wall glycoproteins associated with cellulose & cell walls & $\approx 10 \%$ \\
\hline
\end{tabular}

Crude protein content in herbages depends on the phase of the vegetation, fertilization and water supply. Plant maturity affects not only the content but also the proportion of particular protein fractions (soluble, degradable, indigestible; Elizalde et al., 1999). Plants in the earlier phase of vegetation have more NPN mainly composed of $\mathrm{N}-\mathrm{NH}_{3}$, nitrates, amines, amides and free amino acids. Fertilization, especially mineral, has influence on plant physiology and leads to changes in the content of particular nitrogen fractions. The increase of nitrogen in soil increases total nitrogen content, but the pool of NPN grows faster than the pool of protein nitrogen. Nitrogen fertilization reduces undegradable protein fraction in the rumen which flows bypass to the intestine (Jones, 2000).

Changes in the chemical composition and quality of herbages begin at the time of cutting plants (Table 2). During wilting first proteolytic changes take place. The scope of proteolysis during wilting depends on the rate and extent of water losses. Kemble and Macpherson (1954) observed that during a 3-day wilting more than 20\% of plant protein degraded to NPN. Increasing the concentration of amino acid nitrogen, ammonia and amide nitrogen affected by 26.5 hours of wilting is convergent with the reduced content of true protein (Stallings et al., 1981).

Wilting on windrows of red clover and lucerne up to $40 \%$ DM affects the increase in buffer soluble nitrogen fraction (BSN), particularly its non-protein and free amino acids part. Differences between legume species were found. During wilting of lucerne, herbage contribution of soluble proteins decreased while the proportion of non-protein compounds increased. Contrary to lucerne, in red clover rapidly soluble protein fraction increased, and such a dynamic increase of free amino acid nitrogen was not found. Also, significant losses of peptides were observed (Purwin et al., 2014 a).

In the first phase of ensiling, at raised temperature conditions, the activity of plant proteases increases and extensive hydrolysis of proteins to amino acids occurs (Duniére et al., 2013). Furthermore, at this time enterobacteria affect decarboxylation and deamination of amino acids and the decay of nitrates. As a result of these changes nitrogen oxide and dioxide, ammonia, and biogenic amines are created (Lin et al., 1992). Rapid rise in temperature depends on the weight and density of ensiled material, differing in duration and the amplitude of temperatures (Guo et al., 2007). 


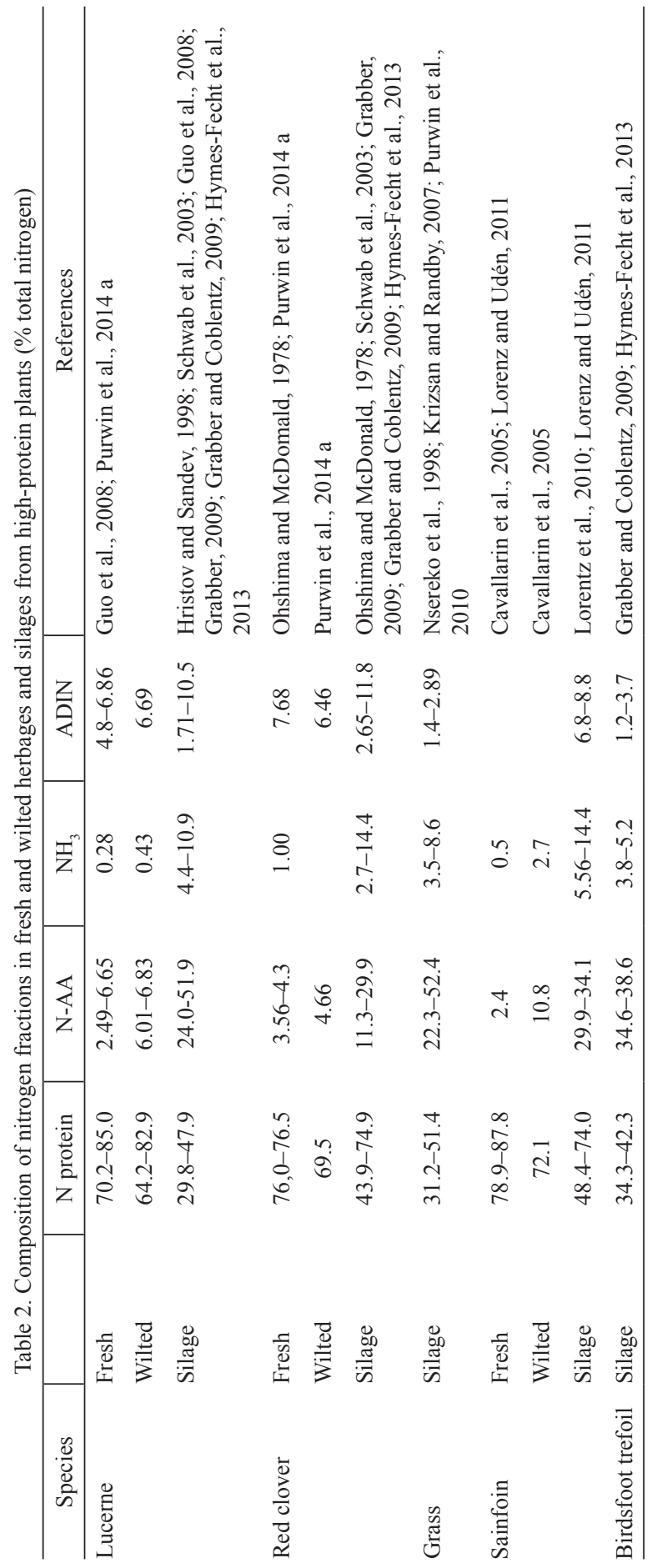


During fermentation the proteases activity is rapidly reduced, and the activity of enterobacteria is maintained to achieve the $\mathrm{pH}$ of the silage mass below 5.0. In this phase, the activity of proteolytic enzymes ceases as a result of lowering $\mathrm{pH}$. Plant proteases perform different functions and, depending on plant species, they have a different $\mathrm{pH}$-activity subject to temperature (Jones, 2000). Optimum $\mathrm{pH}$ for the activity of these enzymes is, for lucerne and red clover, 5.5 (Jones et al., 1995) and 6.5 and 7.0 respectively (McKersie, 1985). However, the majority of plant enzymes retains $15-30 \%$ of its activity at $\mathrm{pH} 4.0$. Cutting time affecting the increase in the WSC content causes an increase in acid production during fermentation, resulting in a faster rate of $\mathrm{pH}$ drop and inhibits protein degradation (Owens et al., 1999).

While the degree of protein hydrolysis in the plant material is the effect of plant enzymes action, decomposition of free amino acids is limited by enterobacterial activity, species composition of lactic acid bacteria and the growth of proteolytic bacteria (Winters et al., 2001).

The final products of the proteolytic transformation during ensiling are non-protein nitrogen compounds including free amino acids, amines and ammonia (Purwin et al., 2009). This fraction is greatest in lucerne silages and may constitute, according to different authors, from 44 to $87 \%$ of total nitrogen (Luchini et al., 1997; Kung and Muck, 2006), and from 7 to $40 \%$ of total nitrogen in red clover (Papadopoulos and McKersie, 1983).

After opening the silo before silage feed-out, reheating of the ensiled material may occur. In both these phases, under the influence of temperature and oxygen, Maillard reaction may occur which involves condensation of a carbonyl group of a reducing sugar with a free amino group of the amino acid, peptide or protein. The rate of this reaction may be nine thousand times faster at $70^{\circ} \mathrm{C}$ than at $10^{\circ} \mathrm{C}$. Silage nitrogen is then bound in complexes with carbohydrates indigestible for animals, included in the acid detergent insoluble nitrogen (ADIN; Purwin et al., 2014 b). With mild effect of the temperature factor the lowering of lysine availability occurs. With the increased intensity of heating, the Maillard reaction can avoid the formation of 1-amino-1-deoxyketose, which results in the damage to other amino acids, such as arginine, tryptophan, cystine, histidine (Michalska and Zieliński, 2007).

The presence of the oxygen kept in the ensiled material extended the survival of enterobacteria in the storage period, which can start a re-growth and development at the moment of feed-out phase by re-exposure to oxygen and an increase in $\mathrm{pH}$. At the same time nitrogen fractions are used by aerobic bacteria and mold.

Mutual proportions between particular forms of non-protein nitrogen (Table 2) depend on the rate of amino acids degradation (Givens and Rulquin, 2004). Breakdown of amino acids occurs in the fermentation process, in which the proteolytic clostridia (especially $C$. sporogenes and C. bifermentans) selectively degrade amino acids by deamination, decarboxylation and in Stickland reactions (McDonald et al., 1991; Jones, 2000). In the amino acids (AA) decarboxylation, a major role is played by Enterobacteriaceae which reduce nitrate to nitrite, fermented hexose to acetic acid, formic acid and ethanol, thereby inhibiting the development of clostridia (Krzywiecki et al., 2008), and lactic acid bacteria, which also have the ability to deaminate amino acids to serine and arginine. Qualitative changes in the amino acid compo- 
sition of silage protein (Figure 2) occurring as a result of deamination and decarboxylation, involve an increased contribution of alanine (Jones, 2000), methionine and branched chain amino acids, and reduce levels of amino acids such as arginine, histidine (Givens and Rulquin, 2004), and the formation of biogenic amines in silage (histamine, tyramine, cadaverine and putrescine; Gąsior and Brzóska, 1999).

Amino acids in the feeds may thus be in the form of peptide bonds and in free forms. Contribution of the free forms in relation to the total quantity of individual amino acids can show differences in the hydrolytic properties of proteins.

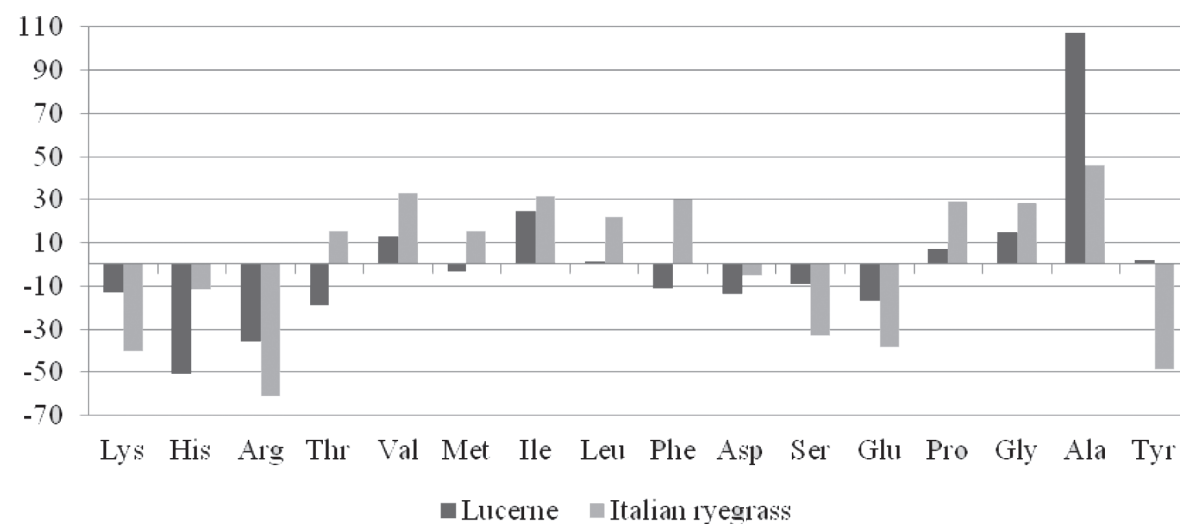

Figure 2. Change (\%) in amino acid composition of wilted lucerne and Italian ryegrass silages as compared to herbage (Givens and Rulquin, 2004)

Participation of free amino acids is the result of their release in the process of proteolysis and peptydolysis, and losses as a consequence of deamination and decarboxylation. A significant impact on the proportion of free amino acids is exerted by the conversion of certain amino acids into others in Stickland reactions. During wilting and ensiling, the process of changing the amino acid composition of protein in hydrolysates occurs, which has been confirmed in numerous studies (Winters et al., 2001; Givens and Rulquin, 2004), but the change in the forms of individual amino acids also takes place. The use of amino acids introduced into the rumen in free form and in the form of peptides or proteins can vary considerably. The extent of these changes may affect the effectiveness of the utilization of particular amino acids and the utilization of nitrogen at all. Minimizing hydrolysis of protein and consequent catabolism of amino acids can potentially reduce the demand for energy necessary for the synthesis of amino acids de novo, and it can improve the efficiency of protein synthesis. Most studies concerning changes in amino acid composition were related to changes in the composition of protein hydrolysates of silages or changes in the contribution of total free amino acids during ensiling.

While comparing different methods of preserving herbages, Arrigo (2006) observed the largest deviation from the total initial content of AA in the amino acid composition of the protein of dried grass as hay on the swath and explained these losses of leaves during machining, cutting and tedding four times. 
Research on the various species of Lactobacillus sp. indicate that proteolytic systems in these bacteria differ in activity. Very strong proteolytic action is characteristic of the strains L. helveticus, L. paracasei sp., L. paracasei, L. acidophilus, L. casei and L. buchneri subsp. bulgaricus delbrueki (Sasaki et al., 1995) and Enterococcus faecalis (Hegazi, 1987). Morishita et al. (1981) and Chopin (1993) observed that lactic acid bacteria are microorganisms with a high requirement for free AA and peptides. If the concentration of amino acids in the free form in herbage is too low, the hydrolysis of proteins to amino acids is required for the growth of lactic acid bacteria and for achieving a sufficient acidification of silage. Proteases of lactic acid bacteria hydrolyze the protein to oligopeptides consisting of 4-8 amino acids outside the cell, then they are received to the cell (Kunji et al., 1996) and hydrolyzed by intracellular aminopeptidases. Thus released amino acids are again incorporated in the bacterial proteins or they are catabolized by them, but they do not return in a free form to the silage environment (Van Boven and Konigs, 1988). In the study by Purwin et al. (2014 a), wilting of lucerne and red clover herbages increased the amount of amino acids linked by a peptide bond without deterioration in the amino acid profile. But losses in exogenous amino acids limiting milk protein synthesis, i.e. Lys, Met, Hys, Arg, were not observed.

\section{Indicators of protein degradation in silage}

Indicators which characterize degradation of nitrogen compounds in silage include contribution of protein and non-protein nitrogen (Licitra et al., 1996) and ammonia nitrogen in the total nitrogen (Davies et al., 1998; Brzóska et al., 1999; Jones, 2000; Purwin et al., 2006; Guo et al., 2008, 2011) as a result of hydrolysis and deamination, respectively. The extent of protein hydrolysis during ensiling is defined as the ratio of protein nitrogen in silage to the amount of protein nitrogen in herbage before ensiling. A precise indicator of protein hydrolysis is free amino acid nitrogen content in silage (Jones, 2000; Winters et al., 2001; Givens and Rulquin, 2004), as well as water-soluble nitrogen (Slottner and Bertilsson, 2006), or in buffer (Hedqvist and Udén, 2006). An indicator of changes in the quality of protein, as a result of oxygen and thermal processes in silage, is acid detergent (ADIN) and neutral detergent insoluble nitrogen (NDIN) content.

Currently used systems of feed evaluation take into consideration the specific character of nitrogen transformations in the digestive tract of ruminants, dividing protein into degradable and undegradable in the rumen (IZ PIB-INRA, 2009). American Cornell Net Carbohydrate and Protein System (CNCPS; Sniffen et al., 1992) unifies diverse methods of separation of nitrogen fractions. It adopts solubility in borate-phosphate buffer and neutral and acid detergent as a criterion for the partition of nitrogen compounds. Simultaneously, the susceptibility of these compounds to enzymatic degradation in the gastrointestinal tract of ruminants is defined and shown in Figure 3. This system allows the assessment of changes in protein quality during preservation and storage of forages, however, it requires making the analytical separation of nitrogen fraction into protein nitrogen and non-protein nitrogen compounds, determination of buffer soluble nitrogen (BSN), buffer soluble protein nitrogen (BSPN), non-protein buffer soluble nitrogen (NPBSN) and an additional 
separation of less soluble nitrogen and completely insoluble compounds (NDIN, ADIN).

\begin{tabular}{|c|c|c|c|c|}
\hline \multicolumn{5}{|c|}{ Crude protein } \\
\hline \multicolumn{4}{|c|}{ True protein } & $\begin{array}{c}\text { A } \\
\text { Non-protein }\end{array}$ \\
\hline \multicolumn{3}{|c|}{ Buffer insoluble protein } & $\begin{array}{c}\mathbf{B}_{1} \\
\text { Buffer soluble }\end{array}$ & \\
\hline \multicolumn{2}{|c|}{ Neutral detergent insoluble protein } & $\begin{array}{c}\mathbf{B}_{2} \\
\text { Neutral } \\
\text { detergent } \\
\text { soluble protein }\end{array}$ & & \\
\hline $\begin{array}{c}\mathbf{C} \\
\text { Acid detergent } \\
\text { insoluble } \\
\text { protein }\end{array}$ & $\begin{array}{c}\mathbf{B}_{3} \\
\text { Acid detergent } \\
\text { soluble protein }\end{array}$ & & & \\
\hline
\end{tabular}

Figure 3. Protein fractions by Cornell Net Carbohydrate and Protein System (Nadeau et al., 2012)

For additional information on nitrogen transformations in silo, it is necessary to isolate the peptide nitrogen, amino acid nitrogen and ammonia nitrogen, as well as to evaluate changes in the status of individual amino acids during ensiling of peptide linkages to free amino acids and determine the content of biogenic amines in silage, as the resulting product in the process of decarboxylation of free amino acids.

\section{Factors affecting the proteolysis and methods of restriction}

The rate and extent of proteolysis during ensiling are influenced by many factors (Duniére et al., 2013). The most important of them are: species of ensiled plants (Papadopoulos and McKersie, 1983; Albrecht and Muck, 1991), dry matter content in ensiled forage (Macpherson and Slater, 1959), the rate of $\mathrm{pH}$ change (Scalet et al., 1984; McKersie, 1985) and temperature (Muck and Dickerson, 1988).

Dry matter content and $\mathrm{pH}$ in ensiling material are considered as the most important factors to proteolysis, and may be modified while species of ensiled plants becomes a factor that strongly influences the rate of proteolysis with a lower degree of wilting (Wilkins, 1984; Jones, 2000; Edmunds et al., 2012). During wilting of herbages, the range of proteolysis depends on the rate of water losses from the cells (McDonald et al., 1991). Pitt et al. (1985) showed that even a slight increase in dry matter content has a large effect on the rate of proteolysis. Wilting not always improves the quality of nitrogen compounds in silage. In good weather conditions it can improve fermentation quality and reduce silage effluent (Dawson et al., 1999), as well as improve the quality of silage protein by its protection against hydrolysis (Hristov and Sandew, 1998). However, wilting is the process during which there is a rapid increase in the pool of free amino acids, peptides, and amides.

Proteolytic potential is closely connected with the species of ensiled plants and depends on the overall activity of proteases contained in the cells and the availability 
of susceptibility of protein substrates to proteolysis (Ohshima and McDonald, 1978; Guo et al., 2007). A species feature is also the content of water soluble carbohydrates (WSC), buffer capacity and the presence of proteolysis inhibitors (Slottner and Bertilsson, 2006; King et al., 2012; Lee et al., 2012). Buffer capacity and WSC content are key factors for the rate of change in $\mathrm{pH}$ during ensiling (McDonald et al., 1991). One factor strongly related to the species is the presence of natural mechanisms protecting the protein, i.e. the activity of polyphenol oxidase (PPO) and tannins which form complexes resistant to proteolysis (Min et al., 2003; Lee et al., 2006). Polyphenol oxidase converts the polyphenols present in the plant to quinones, which are highly reactive and readily form polymers, which are resistant to the activity of proteases and subsequently inactivate plant proteases (Lee et al., 2006; Sullivan and Hatfield, 2006). This is accompanied by the reduction of proteolysis size in the silage, and reduction of losses of the polyunsaturated fatty acids as PPO inhibits lipolysis by deactivating plant lipases (Lee et al., 2004). These processes are the most intense during the ensiling of red clover. Proteins protected in this way may account for $80 \%$ of true protein contained in the silage, resulting in an improvement in the utilization of nitrogen in the rumen (Winters and Minchin, 2001). Polyphenol oxidase in plants occurs in two forms: active (approx. 10\%) and latent (approx. 90\%). The first one exhibits activity within the cells at neutral $\mathrm{pH}$, while the second one requires activation (Lee et al., 2008). In intact tissues, activation of PPO does not occur through compartmentation of enzyme (chloroplast) and the substrate (vacuole). To be activated, PPO requires a simultaneous damage of plant tissues (binding enzyme and substrates) and the presence of oxygen. These conditions are met to varying degrees during ensiling. Red clover silages with low PPO activity contained 25 and 20\% respectively of less soluble nitrogen and free amino acid nitrogen than red clover silage with higher enzyme activity (Winters and Minchin, 2001). Significantly reduced PPO activity is characteristic of lucerne (Lee et al., 2008). In the research, Purwin et al. (2015) found different reaction of these two legume species to ensiling with regard to all fractions. Ensiling of lucerne had a stronger impact on reduction of the contribution of protein nitrogen and increased the soluble fraction as compared to red clover. The smallest changes occurred in the content of nitrogen in the soluble protein form and nitrogen in the NDIN and ADIN forms. High contribution of protein nitrogen in red clover ensiled in bales was accompanied by a large fraction of insoluble nitrogen and the low contribution of amino acids in the hydrolyzate. A large fraction of the protein nitrogen does not necessarily imply a greater nutritional value of the protein in red clover silage as it may contain a large number of fractions that are non-hydrolyzed in the intestine and by bacteria.

Apart from wilting, reduced degradation of protein in silage is obtained by proper direction of fermentation processes and acceleration of acidification by the addition of acids or bacterial inoculation (Weinberg and Muck, 1996; Pyś et al., 2000; Winters et al., 2001; Givens and Rulquin, 2004). Proteolysis is very often inhibited by additives used as inhibitors and stimulators of fermentation. A typical fermentation inhibitor, which is also an inhibitor of proteolysis, is formic acid. On the one hand, by acidification it acts restrictively on fermentation and limits the bacterial deamination and decarboxylation; on the other hand, it reduces the activity of plant proteases 
(Woolford, 1984; Brzóska et al., 1994; 1995 a, b; Hertig and Potkański, 2001; Kung et al., 2003; Guo et al., 2007, 2008; Dorszewski, 2009). Formic acid, due to its low production costs and high acidification capacity, has become the basic component of additives which inhibit fermentation and proteolysis (McDonald et al., 1991; Lindgren, 1999; Randby, 2000; Johansson et al., 2002; Nagel and Broderick, 1992; Polan et al., 1998; Nadeau et al., 2000; Winters et al., 2001; Guo et al., 2008; Purwin et al., 2010; Lorenz and Udén, 2011).

Reduction of deamination in silage and increased contribution of protein nitrogen may also be obtained by using bacterial inoculants (Merry et al., 1997; Winters et al., 2001; Lee et al., 2008). The effectiveness of proteolysis inhibitors depends on the applied dose whereas the effectiveness of bacterial inoculants heavily relies on the number of colony forming units and their viability (Davies et al., 2005). Beneficial effect of fermentation inhibitors or sorbents, as well as wilting of raw materials on the level and rate of protein degradation was found by Brzóska et al. (1999) and Guo et al. (2008).

Protection of protein from degradation during ensiling is also achieved by the use of additives which form protein complexes resistant to enzymatic degradation, i.e. formaldehyde or tannins, or by the use of plants with high tannin content in mixtures, for example birdsfoot trefoil and white clover (Potkański et al., 2002; Burggraaf et al., 2008; Copani et al., 2014). After release from the cells, it binds plant protein, making it resistant to degradation by proteases, both in silo and in the rumen (Jones et al., 1995; Davies et al., 2005), thus reducing its solubility and concentration of ammonia in the rumen fluid (Chiquette et al., 1989), and increases the amount of non-ammonia nitrogen reaching the small intestine (Waghorn et al., 1987). It potentially improves the efficiency of nitrogen utilization in rations for cows (Coblentz and Grabber, 2013). Barry and McNabb (1999) showed that the content of tannins in the rumen reduces proteolysis by approx. $5 \%$ and increases the productivity of animals. These compounds influence the digestibility of feed ingredients and animal productivity, both negatively and positively, depending on the concentration in feeds and their biological activity. They can cause a reduction in protein digestibility in vivo and losses of nitrogen in the feces, a decrease in feed intake, the inhibition of the endogenous digestive and microbial enzymes activity, and reduce losses of endogenous proteins (Getachew et al., 2001; Frutos et al., 2004; Theodoridou et al., 2012). Efficiency of tannins and formaldehyde can be increased by combination with the addition of formic acid. As a result, two goals are achieved: a decrease in the $\mathrm{pH}$ outside the plant enzymes tolerance as well as binding of plant proteins in complexes (Guo et al., 2007).

Attempts at limiting proteolysis in the silage by treatment of herbages with gamma radiation (Heron et al., 1986; Charmley and Veira, 1991), and the addition of metal ions with formic acid to ensiled herbages (Brzóska et al., 1999) have also been carried out. However, no inhibitory effect of these factors on the proteolytic activity of hydrolases was obtained.

Using the Maillard reaction, Broderick et al. (1993) studied the effect of the thermal treatment on the protection of proteins from proteolysis in silo. Temperature $100^{\circ} \mathrm{C}$ for 2 minutes before the lucerne ensiling decreased protease activity by $34 \%$ 
and increased the efficiency of the bacterial protein synthesis by $28 \%$. The effect of this is to increase the amount of amino acids reaching the small intestine by $42 \%$ (Charmley and Veira, 1990).

\section{Conclusions}

Composition of nitrogen fractions will vary depending on plant species. During ensiling numerous transformations in its chemical composition occur as a result of lowering $\mathrm{pH}$ caused by fermentation of carbohydrates and protein to organic acids. The degree and extent of these changes is the result of proteolytic activity of plant and microbial enzymes and protein substrates supply depending on the species of ensiled plants. These processes are accompanied by a change of amino acid composition of protein and a decrease in the intestinal digestibility of dietary protein as a result of the formation of indigestible complexes with carbohydrates (ADIN). Proteolytic processes during wilting and ensiling are accompanied by changes in the proportions of individual amino acids, as well as increase in the share of amino acids in free forms. These changes result from the supply of free amino acids created in the process of proteolysis and peptidolysis and due to losses from deamination and decarboxylation.

The extent of proteolysis processes during ensiling of high-protein herbages influencing the efficiency of nitrogen use in ruminants depends on selection of plant species and the technology of ensiling.

In practice, limiting of proteolysis is achieved by addition of acidifying fermentation inhibitors to the natural moisture herbage in one-phase system technology. The second way is wilting of herbages to $35-40 \%$ DM before ensiling in two-phase system technology. Regardless of the technology, a high density of plant material is one of the most significant factors limiting protein degradation during ensiling.

\section{References}

A 1 b r e cht K.A., M u ck R.E. (1991). Proteolysis in ensiled forage legumes that vary in tannin concentration. Crop Sci., 31: 464-469.

Arrig o Y. (2006). Influence du cycle, du state et du mode de conservation sur la teneur en acides amines des fourrages. Rev. Suisse Agric., 38: 247-255.

B a r ry T.N., M c N a b b W.C. (1999). The implication of condensed tannins on the nutritive value of temperate forages to ruminants. Brit. J. Nutr., 81: 263-272.

B r o d e r i c k G.A., Yan g J.H., K o e g e 1 R.G. (1993). Effect of steam heating alfalfa hay on utilization by lactating dairy cows. J. Dairy Sci., 76: 165.

Brzóska F., Sala K., Kryszczak M. (1994). Effect of mineral and organic acid salts mixture on fermentation profiles and silage chemical composition (in Polish). Rocz. Nauk. Zoot., 21: $215-226$.

B r zó s k a F., W i e w i ó r a W., G ą s i or R., B r zó s k a B. (1995 a). Effect of chemical preservatives on the nutritional values of grass silages, cow productivity and milk composition (in Polish). Rocz. Nauk. Zoot., 22: 149-162.

B r zó s k a F., Z y z a k W., S a l a K. (1995 b). Effect of mixtures of organic acid and mineral acid salts nutritive value of grass silages, cow productivity and milk composition (in Polish). Rocz. Nauk. Zoot., 22: 183-195. 
B rzó s k a F., P i e s z k a M., S a la K. (1999). Effect of dry matter and fermentation supplements on the chemical composition and protein degradation in lucerne silages (in Polish). Rocz. Nauk. Zoot. Ann. Anim. Sci., 26: 231-242.

B urggra a f V., Waghorn G., Wo odw a rd S., Tho m E. (2008). Effects of condensed tannins in white clover flowers on their digestion in vitro. Anim. Feed Sci. Tech., 142: 44-58.

Buxt on D.R., O'Ki ely P. (2003). Preharvest plant factors affecting ensiling. In: Buxton D.R., Muck R.E., Harrison J.H. (eds). In: Silage Science and Technology. Wisconsin, USA, American Society of Agronomy, pp. 199-250.

Cavallarin L., Antoniazzi S., Borreani G., Tabacco E. (2005). Effects of wilting and mechanical conditioning on proteolysis in sainfoin (Onobrychis viciifolia Scop) wilted herbage and silage. J. Sci. Food Agr., 85: 831-838.

Charmley E., Veir a D.M. (1990). Inhibition of proteolysis in alfalfa silages using heat at harvest: effects on digestion in rumen, voluntary intake and animal performance. J. Anim. Sci., 68: 2042-2051.

Ch a r m l e y E., Ve i r a D.M. (1991). The effect of heat-treatment and gamma-irradiation on the composition of unwilted lucerne silages. Grass Forage Sci., 46: 381-390.

Ch i que t te J., Cheng K.J., R o de L.M., Milli ga n L.P. (1989). Effect of tannin content in two isosynthetic strains of birdsfoot trefoil (Lotus corniculatus) on feed digestibility and rumen fluid composition in sheep. Can. J. Anim. Sci., 69: 1031-1039.

Chop in A. (1993). Organization and regulation of genes for amino acid biosynthesis in lactic acid bacteria. FEMS Microbiol. Rev., 12: 21-38.

Coblentz W.K., Grabber J.H. (2013). In situ protein degradation of alfalfa and birdsfoot trefoil hays and silages as influenced by condensed tannin concentration. J. Dairy Sci., 96: 3120-3137.

Copani G., Ginane C., Le Morvan A., Niderkorn V. (2014). Bioactive forage legumes as a strategy to improve silage quality and minimise nitrogenous losses. Anim. Prod. Sci., 54: 1826-1829.

Davi e s D.R., Merry R.J., Will i a m s A.P., B a kew e 11 E.L., L e e m a n s D.K., Tw e e d J.K. (1998). Proteolysis during ensilage of forages varying in soluble sugar content. J. Dairy Sci., 81: $444-453$.

Davie s D.R., Winters A.L., L e e mans D.K., Dhan o a.S., Merry R.J. (1999). The effect of inoculant treatment of alternative crop forages on silage quality and in vitro rumen function. Proc. XIIth International Silage Conference, Uppsala, Sweden, 2-4.07.2012, pp. 131-132.

Davi es D.R., The odorou M.K., K ing ston-S mith A.H., Merry R.J. (2005). Advances in silage quality in the 21 st century. Proc. XIVth International Silage Conference, Belfast, Northern Ireland, 05.2005, pp. 121-133.

D a w s o n L.E.R., F e r r is C.P., S t e e n R.W.J., G or d o n F.J., K i 1 p a tr i c D.J. (1999). The effects of wilting grass before ensiling on silage intake. Grass Forage Sci., 54: 237-247.

D ewhurst R.J., Mitt on A.M., Offer N.W., Thom a s C. (1996). Effects of the composition of grass silages on milk production and nitrogen utilization by dairy cows. Anim. Sci., 62: 25-34.

Dewhurst R.J., Scollan N.D., Moorby J.M., Evans R.T., Merry R.J., Wilkins R.J. (2003). Comparison of grass and legume silages for milk production. 2. In vivo and in sacco evaluations of rumen function. J. Dairy Sci., 86: 2612-2621.

D orszewski P.A. (2009). The effectiveness of the use of silage additives in the preservation of legume-grass mixture and whole maize herbages (in Polish). Dissertations no 136. Wydawnictwa Uczelniane Uniwersytetu Technologiczno-Przyrodniczego.

Duniére L., Sindou J., Chaucheyras-Durand F., Chevallier I., Thévenot-Serge n tet D. (2013). Silage processing and strategies to prevent persistence of undesirable microorganisms. Anim. Feed Sci. Tech., 183: 1-15.

Edmunds B., Spiekers H., Südekum K.-H., Nus sbaum H., Schwarz F.J., Ben$\mathrm{n}$ e t t R. (2012). Effect of extent and rate of wilting on nitrogen components of grass silage. Grass Forage Sci., 69: 140-152.

Elizald e J.C., M e r c h e n N.R., F a u lkn e r D.B. (1999). Fractionation of fiber and crude protein in fresh forages during the spring growth. J. Anim. Sci., 77: 476-484.

Frank B., Pers on M., Gustafs s on G. (2002). Feeding dairy cows for decreased ammonia emission. Livest. Prod. Sci., 76: 171-179. 
Frutos P., Hervás G., Girálde z F.J., Man tecón A.R. (2004). Review. Tannins and ruminant nutrition. Span. J. Agric. Res., 2: 191-202.

Gą s i or R., Brzósk a F. (1999). The type and level of biogenic amines in alfalfa and red clover silage (in Polish). Zesz. Nauk. AR Kraków, 347: 89-94.

G ą s i o r R., B r zó s k a F. (2002). Biogenic amines in silages (in Polish). Adv. Agr. Sci., 2: 115-128.

Get a chew G., Makkar H.P.S., Becker K. (2001). Method of polyethylene glycol application to tannin-containing browses to improve microbial fermentation and efficiency of microbial protein synthesis from tannin containing browses. Anim. Feed Sci. Tech., 92: 51-57.

G i ve n s D.I., R u lqu in H. (2004). Utilization by ruminants of nitrogen compounds in silage-based diets. Anim. Feed Sci. Tech., 114: 1-18.

G r a b b e r J.H. (2009). Forage management effects on protein and fiber fractions, protein degradability, and dry matter yield of red clover conserved silage. Anim. Feed Sci. Tech., 154: 284-291.

Gra b b e r J.H., C o b l e n t z W.K. (2009). Polyphenol, conditioning, and conservation effects on protein fractions and degradability in forage legumes. Crop Sci., 49: 1511-1522.

Gu o X., Zhou H., Yu Z., Zhang Y. (2007). Changes in the distribution of nitrogen and plant enzymatic activity during ensilage of lucerne treated with different additives. Grass Forage Sci., 62: $35-43$.

Gu o X.S., D ing W.R., H a n J.G., Z h o u H. (2008). Characterization of protein fractions and amino acids in ensiled alfalfa treated with different chemical additives. Anim. Feed Sci. Tech., 142: 89-98.

Guo X.S., Cheng W., Zhang Y., Yang F.Y., Zh ou H. (2011). Contribution of endopeptidases to the formation of nonprotein nitrogen during ensiling of alfalfa. Anim. Feed Sci. Tech., 168: 42-50.

H e dqvis t H., U dé n P. (2006). Measurement of soluble protein degradation in the rumen. Anim. Feed Sci. Tech., 126: 1-21.

H e g a z i F.Z. (1987). Proteolytic activity of lactic acid bacteria in skim milk with special reference to the biodegradation of casein fractions. Nahrung., 31: 19-26.

Heron S., Edwards R.E., McDonald P. (1986). Changes in the nitrogenous components of gamma-irradiated and inoculated ensiled ryegrass. J. Sci. Food Agric., 37: 979-985.

Hertig D., Potkański A. (2001). The effect of additives on carbohydrate content of grass and legume silages (in Polish). Ann. Anim. Sci., 13: 35-40.

H r i s to v A.N., S a n d e v S.G. (1998). Proteolysis and rumen degradability of protein in alfalfa preserved as silage, wilted silage or hay. Anim. Feed Sci. Tech., 72: 175-181.

$\mathrm{Huhtanen} \mathrm{P.} \mathrm{(2010).} \mathrm{Evaluation} \mathrm{of} \mathrm{protein} \mathrm{value} \mathrm{of} \mathrm{forages.} \mathrm{Proc.} \mathrm{14th} \mathrm{International} \mathrm{Symposium}$ "Forage Conservation", Brno, 17-19.03.2010, pp. 58-76.

$\mathrm{Huh}$ tan en P., Shing fi eld K.J. (2005). Grass silage: factors affecting efficiency N utilization in milk production. Proc. XIVth International Silage Conference, Belfast, Northern Ireland, 07.2005, pp. 35-51.

H y m e s - F e ch t U.C., B r o d e r i ck G.A., M u c k R.E., Grabber J.H. (2013). Replacing alfalfa or red clover silage with birdsfoot trefoil silage in total mixed rations increases production of lactating dairy cows. J. Dairy Sci., 96: 460-69.

IZ PIB-INRA (2009). Standards for ruminant feeding. The nutritional value of the French and the national feeds for ruminants (J. Strzetelski ed.), IZ PIB, Kraków.

Johans s on M., B a g ge E., Thy 1 in I., A 1 bi hn A. (2002). Hygienic quality in grass silage in relation to dry matter content of the crop. Proc. XIIIth International Silage Conference, Auchincruive, Scotland, pp. 404-405.

J o n e s R. (2000). Understanding the processes of protein degradation in forage crops provide opportunities for improved silage quality and enhanced animal production. Proc. Alltech's Sixteenth Annual Symposium, Lyons T.P. and Jacques K.A. (eds). Nottingham University Press, pp. 423-437.

J o n e s B.A., M u ck R.E., Hatfi eld R.D. (1995). Red clover extracts inhibit legume proteolysis. J. Sci. Food Agr., 67: 329-333.

K e m b le A.R., M a c pher s o n H.T. (1954). Liberation of amino acids in perennial rye grass during wilting. Biochem. J., 58: 46.

K in g C., M c En iry J., O ' K i e ly P. (2012). A note on the fermentation characteristics of red clover silage in response to advancing stage of maturity in the primary growth. Irish J. Agr. Food Res., 51: 79-84. 
Krizsan S.J., Randby $\AA . T$. (2007). The effect of fermentation quality on the voluntary intake of grass silage by growing cattle fed silage as the sole feed. J. Anim. Sci., 85: 984-996.

Krzyw i e cki S., Preś J., B od arski R. (2008). The importance of microbiological and physicochemical processes in the practice of ensiling forage in German research (in Polish). Pam. Puł., 147: $139-150$.

K u n g L. Jr., S to c ke s M.R., L i n C.J. (2003). Silage additives. In: Silage Science and Technology, Buxton D.R., Muck R.E, Harrison J.H. (eds). Agronomy Series, 42, Madison, Wisconsin, USA, pp. $305-360$.

K u n g L. Jr., M u c k R.E. (2006). Preservation of protein during harvest and storage. J. Dairy Sci., 89 (Suppl. 1): 449.

Kunji E.R.S., Miera u I., Hagting A., P o olman B., Kon ing s W.N. (1996). The proteolytic system of lactic acid bacteria. A. Van Leeuw. J. Microb., 70: 187-221.

Lee M.R.F., Winters A.L., Scollan N.D., Dewhurst R.J., Theodorou M.K., Min$\mathrm{c}$ h in F.R. (2004). Plant-mediated lipolysis and proteolysis in red clover with different polyphenol oxidase activites. J. Sci. Food Agr., 84: 1639-1645.

Lee M.R.F., Olmos Colmenero J.J., Winters A.L., Scollan N.D., Minchin F.R. (2006). Polyphenol oxidase activity in grass and its effect on plant-mediated lipolysis and proteolysis of Dactylis glomerata (cocksfoot) in a simulated rumen environment. J. Sci. Food Agr., 86: 1503-1511.

L e e M.R.F., S c ot t M.B., Tw e e d J.K.S., M in ch in F.R., D a v i e s D.R. (2008). Effects of polyphenol oxidase on lipolysis and proteolysis of red clover silage with and without a silage inoculant (Lactobacillus plantarum L54). Anim. Feed Sci. Tech., 144: 125-136.

L e e M.R.F., Twe ed J.K.S., Sullivan M.L. (2012). Oxidation of ortho-diphenols in red clover with and without polyphenol oxidase (PPO) activity and their role in PPO activation. Grass Forage Sci., 68: 83-92.

L i c itra G., Her n a n d e z T.M., Van S o e s t P.J. (1996). Standardization of procedure for nitrogen fractionation of ruminant feeds. Anim. Feed Sci. Tech., 57: 347-358.

L in C., B ols en K.K., B rent B.E., Hart R.A., D i ckerson J.T., F e y e rherm A.M., A i mut is W.R. (1992). Epiphytic microflora of alfalfa and whole-plant corn. J. Dairy Sci., 75: 2484-2493.

L in d gre n S. (1999). Can HACCP principles be applied for silage safety? Silage production in relation to animal performance, animal health, meat and milk quality. Proc. XIIth International Silage Conference, Uppsala, Sweden, pp. 51-66.

L o r e n z M.M., Eri k s s o n T., U dé n P. (2010). Effect of wilting, silage additive, PEG treatment and tannin content on the distribution of $\mathrm{N}$ between different fractions after ensiling of three different sainfoin (Onobrychis viciifolia) varieties. Grass Forage Sci., 65: 175-184.

L o r e n z M.M., U d é n P. (2011). Influence of formic acid and dry matter on protein degradation in the tanniniferous legume sainfoin. Anim. Feed Sci. Tech., 164: 217-224.

Luchini N.D., Broderick G.A., Muck R.E., Makoni N.F., Vetter R.L. (1997). Effect of storage system and dry matter content on the composition of alfalfa silage. J. Dairy Sci., 80: 1827-1832.

M a c phers on H.T., S l at e r J.S. (1959). $\gamma$-amino-n-butyric, aspartic, glutamic and pyrrolidonecarboxylic acid; their determination and occurrence in grass during conservation. Biochem. J., 71: $654-660$.

Martin e a u R., La pi erre H., O u e 11 e t D.R., P e 11 e r in D., B e r th i a u m e R. (2007). Effects of the method of conservation of timothy on nitrogen metabolism in lactating dairy cows. J. Dairy Sci., 90: 2870-2882.

M c D on ald P., He n d e r s on A.R., H e r o n S.J.E. (1991). The Biochemistry of Silage. Chalcombe Publications, Marlow Bucks, UK, 2nd ed.

M c K ers i e B.D. (1985). Effect of pH on proteolysis in ensiled legume forage. Agron. J., 77: 81-86.

Merry R.J., L ow es K.F., Winters A.L. (1997). Current and future approaches to biocontrol in silage, Jambor V., Klapil L., Chromec P., Prochazka P. (eds). Proc. 8th International Symposium on Forage Conservation, Brno, Research Institute of Animal Nutrition Ltd., Pohorelice, Czech Republic, pp. 17-27.

M i chals k a A., Z i e li ńs ki H. (2007). The Maillard reaction products in food. Food. Science. Technology. Quality, 51: 5-16. 
M in B.R., B a r ry T.N., A t tw o o d G.T., M c N a b b W.C. (2003). The effect of condensed tannins on the nutrition and health of ruminants fed fresh temperate forages: a review. Anim. Feed Sci. Tech., 106: 3-19.

M o orby J.M., D ew hurst R.T., Evan s R.T., F is he r W.J. (2002). Effects of varying the energy and protein supply to dry cows on high forage systems. Livest. Prod. Sci., 76: 125-136.

Morishita T., Deguchi Y., Yajima M., Sakurai T., Yura T. (1981). Multiple nutritional requirements of lactobacilli: genetic lesions affecting amino acid synthetic pathways. J. Bacteriol., 148: 64-71.

Muck R.E., Di ckers on J.T. (1988). Storage temperature effects on proteolysis in alfalfa silage. T. ASAE, 31: 1005-1009.

N a d e a u E.M.G., Buxton D.R., Rus s el J.R., A 11 is on M.J., Young J.W. (2000). Enzyme, bacterial inoculant, and formic acid effects on silage composition of orchadgrass and alfalfa. J. Dairy Sci., 83: 1487-1502.

$\mathrm{N}$ a de a u E., Englund J.E., Gus ta f s s on A.H. (2007). Nitrogen efficiency of dairy cows as affected by diet and milk yield. Livest. Sci., 111: 45-46.

Nadeau E., Richardt W., Murphy M., A uerbach H. (2012). Protein quality dynamics during wilting and preservation of grass-legume forage. Proc. XVIth International Silage Conference, Hämeenlinna, Finland, 2-4.07.2012, pp. 56-57.

$\mathrm{N}$ a g e 1 S.A., B roderi c k G.A. (1992). Effect of formic acid or formaldehyde treatment of alfalfa silage on nutrient utilization by dairy cows. J. Dairy Sci., 75: 140-154.

N s e r e k o V.L., R o o k e J.A., N e w b o ld C.J., W a 11 a c e R.J. (1998). Influence of protease inhibitors on nitrogen distribution in ensiled perennial ryegrass and the utilisation of silage nitrogen for growth by rumen bacteria in vitro. Anim. Feed Sci. Tech., 76: 51-63.

O h s h i m a M., M c D o n a ld P. (1978). A review of the changes in nitrogenous compounds of herbage during ensilage. J. Sci. Food Agr., 29: 497-505.

O w e n s V.N., A 1 bre ch t K.A., M u ck R.E., D u ke S.H. (1999). Protein degradation and fermentation characteristics of red clover and alfalfa silage harvested with varying levels of total nonstructural carbohydrates. Crop Sci., 39: 1873-1880.

P a p a d o p o u l o s Y.A., M c K e r s i e B.D. (1983). A comparison of protein degradation during wilting and ensiling of six forage species. Can. J. Plant Sci., 63: 903-912.

P it t R.E., M u c k R.E., L e i b e n s p e r g e r R.Y. (1985). A quantitative model of the ensilage process in lactate silages. Grass Forage Sci., 40: 279-303.

Polan C.E., S ti e ve D.E., Garrett J.L. (1998). Protein preservation and ruminal degradation of ensiled forage treated with heat, formic acid, ammonia, or microbial inoculant. J. Dairy Sci., 81: $765-776$.

Potkański A., Gulewicz K., Michalak S. (2002). Effect of tannins on the degradability of protein silages in the rumen. Proc. XIIIth International Silage Conference, Auchincruive, Scotland, pp. 306-307.

Purwin C., Łaniewska-Trokenheim Ł., Warmińska-Radyko I., Tywończuk J. (2006). The quality of silage - microbiological, health and production aspects (in Polish). Med. Weter., 62: 865-869.

Purwin C., Pysera B., Tokarczyk M., Sederevicius A., Savickis S., Traidarait è A. (2009). Production results of dairy cows fed grass and alfalfa silage with a different degree of wilting. Vet. Zootec., 46: 60-66.

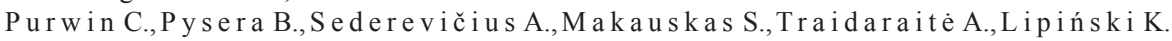
(2010). Effect of silage made from different plant raw materials with the addition of fermentation inhibitor on the production results of dairy cows. Vet. Zootec., 51: 44-51.

Purwin C., Fijałkowska M., Pys era B., Lipiński K., Sienkiewicz S., Piwczyńs ki D., Puzio N. (2014 a). Nitrogen fractions and amino acid content in alfalfa and red clover immediately after cutting and after wilting in the field. J. Elem., 19: 723-734.

P u rw in C., F i jałk o w s k a M., K ow a lik B., S k órko - S a j k o H., No ga ls ki Z., P y s e ra B. (2014 b). The effect of bale density and the addition of formic acid on the in situ dry matter and crude protein degradation of lucerne, red clover and red fescue silages. J. Anim. Feed Sci., 23: $177-184$.

Purwin C., Fijałkowska M., Lipiński K., Wierzbowska J., Kobzhassarov T.Z., 
M i c hals ki J. (2015). Changes in amino acid composition during ensiling lucerne and red clover in round bales. J. Elem. (in press).

P y ś J.B., B or ow i e c F., F u r g ał K., K a m ińs k i J., Z a j ą c T. (2000). The effect of bacterial inoculant, glucose and lactic acid on the quality and chemical composition of alfalfa silage Medicago sativa Pers and Medicago sativa L. (in Polish). Acta Agr. Silv., ser. Zootech., 38: 3-15.

R a n d b y Å.T. (2000). The effect of some acid-based additives applied to wet grass crops under various ensiling conditions. Grass Forage Sci., 55: 289-299.

S a s a k i M., B o s m a n B.W., T a n P.S.T. (1995). Comparison of proteolytic activities in various Lactobacilli. J. Dairy Res., 62: 601-610.

S c a le t M., A l p i A., P i c c i a re 11 i P. (1984). Proteolytic activities in alfalfa (Medicago sativa L.) leaves. J. Plant Physiol., 116: 133-145.

S chwab C.G., Tylutki T.P., Ordw a y R.S., She affer C., Stern M.D. (2003). Characterization of proteins in feeds. J. Dairy Sci., 86(E. Suppl.): E88-E103.

S lottner D., Bertils s o n J. (2006). Effect of ensiling on protein degradation during ensilage. Anim. Feed Sci. Tech., 127: 101-111.

Sniffen C.J., O `Connor J.D., Van Soest P.J., Fox D.G., Rus s e l J.B. (1992). A net carbohydrate and protein system for evaluating cattle diets. II. Carbohydrate and protein availability. J. Anim. Sci., 70: 3562-3577.

Stallings C.C., Townes R., Jess e B.W., Thomas J.W. (1981). Changes in alfalfa haylage during wilting and ensiling with and without additives. J. Anim. Sci., 53: 765-773.

Sullivan M.L., Hatfield R.D. (2006). Polyphenol oxidase and $o$-diphenols inhibit postharvest proteolysis in red clover and alfalfa. Crop Sci., 46: 662-670.

Theodoridou K., A u frère J., Andueza D., Le Morvan A., Picard F., Pourrat J., B a u m o n t R. (2012). Effects of condensed tannins in wrapped silage bales of sainfoin (Onobrychis viciifolia) on in vivo and in situ digestion in sheep. Animal, 6: 245-253.

Van B oven A., Konig s W.N. (1988). Utilization of dipeptides by Lactococcus lactis ssp. cremoris. Biochemie, 70: 535-542.

Van Vuuren A.M. (1993). Digestion and nitrogen metabolism of grass fed dairy cows. Ph.D. diss. Landbouwuniversiteit te Wageningen, The Netherlands.

Wa gh or n G.C., U ly at t M.J., J o hn A., F i s h e r M.T. (1987). The effect of condensed tannins on the site of digestion of amino acids and other nutrients in sheep fed on Lotus corniculatus L. Brit. J. Nutr., 57: 115-126.

We in berg Z.G., Muck R.E. (1996). New trends and opportunities in the development and use of inoculants for silage. FEMS Microbiol. Rev., 19: 53-68.

Wilkins R.J. (1984). A review of the effects of wilting on the composition and feeding values of silages. In: Efficency of silage systems: a comparison between unwilted and wilted silages, Zimmer E. and Wilkins R.J. (eds). Landbauforshung Völkenrode, Sonderheft, 69: 71-77.

W in ters A.L., M in c h in F.R. (2001). Red clover and the future for pasture legumes as an alternative protein source for ruminants. IGER Innovations, 5: 30-33.

W in ters A.L., Fy chan R., J on es R. (2001). Effect of formic acid and a bacterial inoculant on the amino acid composition of grass silage and on animal performance. Grass Forage Sci., 56: 181-192.

W o o 1 f o r d M.K. (1984). Silage fermentation. New York, Marcel Decker.

Received: 5 X 2014

Accepted: 9 XII 2014 